\title{
Changes in the feedback control of gonadotrophin secretion in ewes from lines selected for testis size in the ram lamb
}

\author{
J. R. McNeilly, M. Fordyce, R. B. Land $\dagger$, G. B. Martin*ł, A. J. Springbett \\ and R. Webb
}

A.F.R.C. Institute of Animal Physiology and Genetics Research, Edinburgh Research Station, Roslin, Midlothian EH25 9PS, U.K.; and *M.R.C. Reproductive Biology Unit, Centre for Reproductive Biology, 37 Chalmers Street, Edinburgh EH3 9EW, U.K.

\begin{abstract}
Summary. The dynamics of FSH and LH secretion were studied in sheep genetically selected for High (H) and Low (L) rates of testis growth. Gonadotrophin secretion had previously been shown to be affected in the ram lamb with $\mathrm{H}$-line lambs more sensitive to steroid feedback than L. While there were significant differences in mean LH concentrations during the luteal and follicular phases of the oestrous cycle, mean $\mathrm{LH}$ values were essentially similar in the two lines in response to ovariectomy, the effect of oestradiol implants on the response to ovariectomy and the response to LHRH. However, the frequency of $\mathrm{LH}$ pulses in the $\mathrm{H}$ line was similar during both phases of the oestrous cycle, showing a surprising insensitivity to steroid feedback. By contrast, LH pulse frequency was markedly lower in the L-line ewes in the luteal than the follicular phase $(0.6$ vs 1.1 pulses/h) as expected from the literature. Mean FSH concentrations were significantly higher in the L-line ewes during the follicular phase of the oestrous cycle and after ovariectomy but no significant differences were detected at the other sampling periods. There were no differences in ovulation rate between the lines. It was concluded that selection for testis size had affected the feedback control of gonadotrophin release in the ewe, as in the ram, and hence the expression of the genes controlling this is not sex limited.
\end{abstract}

Keywords: ewes; gonadotrophins; selection; testis diameter

\section{Introduction}

The possibility that the expression of genes controlling variation in reproductive performance is not sex limited (Land, 1973) indicated that the presence of alleles with favourable effects on female reproduction may be identified directly in a male. Subsequently, in lines of mice selected for large testis size, their female offspring were found to have higher ovulation rates (Islam et al., 1976). In Finnish Landrace sheep, a change in testis size has been observed after selection for ovulation rate (Hanrahan \& Quirke, 1982); Knight (1984) showed that ram lambs from high prolificacy ewes had significantly greater testis weight although not necessarily testis diameter, and Purvis et al. (1988) reported a positive genetic correlation between testis size and ovulation rate within a population of Merino sheep. The inclusion of a male trait of moderate heritability and an intermediate genetic

$\dagger$ Deceased.

†Present address: School of Agriculture (Animal Science), University of Western Australia, Nedlands, Western Australia 6009, Australia. 
correlation with ovulation rate in programmes of genetic selection for female performance would give a 2 -fold greater rate of response than selection on the female trait alone (Walkley \& Smith, 1980 ).

Testis size in sheep responded directly to selection but body weight changed in the opposite direction as it was corrected for at the time of selection (Lee \& Land, 1984). The duration of the breeding season and fertility of the lines changed in the same direction as selection while ovulation rate was largely unaffected. Purvis et al. (1988) have estimated the relevant genetic parameters for Merino sheep and shown that the genetic correlation between ovulation rate and body weight underlies this response and that the selection criterion would have to be calculated to at least allow body weight to remain constant.

A previous study of 6-20-week-old ram lambs from the lines which now show a 2-fold difference in testis size indicated inherent differences in the dynamics of FSH release (McNeilly et al., 1986). The presence of such a change in adult females has now been investigated to assess the extent to which this expression of genes controlling variation in gonadotrophin release is sex limited.

\section{Materials and Methods}

Animals. The present study was carried out on $2 \frac{1}{2}$-year-old Finn Dorset ewes from 2 genetically distinct lines established by selection for high $(\mathrm{H})$ and low $(\mathrm{L})$ juvenile testis diameter at 6-14 weeks of age. Details of the selection procedure are described by Lee \& Land (1984). During the experimental period (December-January), all animals were housed under natural lighting and had access to food and water ad libitum.

Experimental design. From each of the 2 selection lines comprising 80 ewes/line, 20 ewes were chosen at random. Peripheral blood samples were collected during the follicular and luteal phases of the oestrous cycle, through ovariectomy and the insertion of an oestradiol implant and following injection of LHRH. To simplify sampling, all animals were treated with progestagen-impregnated vaginal pessaries (Syncro-mate: G. D. Searle \& Co. Ltd, High Wycombe, Bucks, U.K.) for 12 days to synchronize oestrus before the start of the experiment. After sponge removal, ten ewes from each line were fitted with an indwelling jugular venous catheter and transferred to individual metabolism crates (Day -2). Blood samples were collected at 10-min intervals for $6 \mathrm{~h}$ on the following day (Day -1 ; follicular phase). A vasectomized raddled ram was used to detect oestrus in all 40 ewes and tests were made every $6 \mathrm{~h}$ until all ewes showed oestrus (Day 0). Laparoscopy on Day 5 was used to determine ovulation rates. On Day 8, the same 20 ewes were recannulated and blood samples were collected on Day 9 (mid-luteal phase) at 10-min intervals for $8 \mathrm{~h}$. The following oestrus was detected as previously described.

Ovariectomy was carried out and ovulation rate determined in all ewes through a mid-ventral incision on Day 6 after the second oestrus following sponge removal using anaesthesia with alphaxalone:alphadolone (Saffan: Glaxovet Ltd, Uxbridge, U.K.) which, unlike other anaesthetics, does not affect gonadotrophin release. In 10 ewes from each line, a Silastic implant (Dow Corning, Midland, MI, U.S.A.) containing oestradiol was placed subcutaneously in the axillary region while the animals were anaesthetized for ovariectomy. The implants, previously assessed to produce circulating blood levels of 3-4 pg/ml (Webb et al., 1985b), were soaked in tap water overnight then in ethanol for $1 \mathrm{~h}$ before insertion. After ovariectomy, there were 4 experimental groups: $\mathrm{H}$-line ovariectomized (HO, $\mathrm{N}=10$ ); L-line ovariectomized ( $\mathrm{LO}, \mathrm{N}=10)$; H-line ovariectomized + oestradiol implant $(\mathrm{HOI}, \mathrm{N}=10)$; L-line ovariectomized + oestradiol implant (LOI, $N=10$ ). Blood samples were collected at 1 -h intervals for $4 \mathrm{~h}$ then every $4 \mathrm{~h}$ up to $24 \mathrm{~h}$ after ovariectomy. Three 5-ml blood samples were collected at 1 -h intervals from each ewe every 2 days until 2 weeks after ovariectomy.

LHRH dose-response. At Day 15 after ovariectomy, all ewes were challenged with a 2-ml bolus intravenous injection of one of the following; saline, $0.05,0.5$ or $5 \mu \mathrm{g}$ luteinizing hormone-releasing hormone (LHRH; Hoechst, Frankfurt, Germany). On a further 3 occasions, at 3-day intervals, the ewes were injected with one of the remaining doses so that over the entire experimental period each animal was given each treatment. The order in which animals received each dose was chosen at random. Blood samples were withdrawn at $0,30,50$ and 70 min after injection.

At 2 days after the last LHRH challenge, blood samples were collected at 15 -min intervals for $6 \mathrm{~h}$ from only 6 ovariectomized ewes from each line; the remaining 4 animals had received an oestradiol implant and hence were unsuitable for sampling at this time.

Hormone assays. The concentrations of FSH and LH in the plasma samples were measured using radioimmunoassays. Details of the LH assay modified in this laboratory have been described previously (Martensz et al., 1976; Webb et al., 1985b). Plasma FSH concentrations were measured by an homologous assay supplied by NIAMDD. Sequential samples from each animal were measured in duplicate in a single assay to avoid inter-assay variation. The limits of detection of each assay were $0.32 \mathrm{ng} \mathrm{NIH-LH-S18/ml} \mathrm{and} 0 \cdot 15 \mathrm{ng}$ NIAMDD-oFSH-RPI/ml. The intra- and 
inter-assay variations expressed as coefficients of variation (\%) were 4.03 and $11 \cdot 1 \%$ for the LH assay and 3.67 and $9 \cdot 29 \%$ for the FSH assay, respectively.

Plasma oestradiol was measured by the radioimmunoassay of Webb et al. (1985a) after extraction by affinity chromatography on Sepharose-4B. Inter- and intra-assay coefficients of variation were $12 \cdot 5$ and $12 \cdot 1 \%$ respectively. The minimum detectable level was $1.01 \mathrm{pg} / \mathrm{ml}$.

Statistical analysis. The differences in mean concentrations of gonadotrophins between the two selected lines during the periods of frequent blood sampling were investigated by analysis of variance after log transformation. The method of analysis used for the LH pulse frequency and amplitude has previously been described in detail (Webb et al., 1985b).

The LH and FSH responses to ovariectomy and ovariectomy + oestradiol implant were analysed by fitting quadratic response curves to the data, again after log transformation. Analysis was restricted to the periods of rapid change in hormone concentrations before the plateau phases of the response.

For the analysis of LHRH dose-response, baseline gonadotrophin concentrations measured at the first sampling time were subtracted from the measurements made at the second and third sampling times to give the short- and longer-term effects of the dose injected. Analysis of variance was then used to test the effects of line, treatment, LHRH dose and time on LH and FSH.

\section{Results}

\section{Ovulation rate}

At both laparoscopy and ovariectomy, there was no difference in ovulation rate between the $\mathrm{H}$ - and L-line ewes (laparoscopy, $2.7 \pm 0.2(\mathrm{H})$ and $2.6 \pm 0.3(\mathrm{~L})$; ovariectomy $2.6 \pm 0.3(\mathrm{H})$ and $2 \cdot 5 \pm 0 \cdot 3(\mathrm{~L}))$.

\section{Gonadotrophin concentrations during the oestrous cycle}

As shown in Table 1, mean LH concentrations in both lines were significantly higher in the follicular than luteal phase $(P<0.01)$. In the $\mathbf{H}$ line, these higher concentrations in the follicular phase arose from an increase in pulse amplitude (Figs $1 \mathrm{a}, \mathrm{b}$ ), the pulse frequency remaining the same. In the L-line sheep, amplitude remained constant and a higher pulse frequency accounted for the greater mean values. There was no difference between the lines in mean LH at the postovariectomy sampling period, with pulse amplitude in both lines being similar to that observed during the follicular phase in the $\mathrm{H}$ line.

Table 1. Geometric mean \pm s.e.m. concentrations of plasma $\mathrm{LH}$ and FSH during the follicular, luteal and post-ovariectomy sampling periods

\begin{tabular}{|c|c|c|c|c|}
\hline Sampling period & Line & $\begin{array}{l}\text { No. of } \\
\text { ewes }\end{array}$ & $\underset{\text { (ng/ml) }}{\mathrm{LH}}$ & $\begin{array}{c}\text { FSH } \\
\text { (ng/ml) }\end{array}$ \\
\hline Follicular & $\begin{array}{l}\text { H } \\
\mathbf{L}\end{array}$ & $\begin{array}{l}10 \\
10\end{array}$ & $\begin{array}{l}1.86 \pm 0.15^{\mathrm{a}} \\
2 \cdot 61 \pm 0.04^{\mathrm{b}}\end{array}$ & $\begin{array}{l}1 \cdot 13 \pm 0 \cdot 12^{\mathrm{a}} \\
1 \cdot 63 \pm 0 \cdot 12^{\mathrm{b}}\end{array}$ \\
\hline Luteal & $\begin{array}{l}\mathrm{H} \\
\mathrm{L}\end{array}$ & $\begin{array}{l}10 \\
10\end{array}$ & $\begin{array}{l}0.53 \pm 0.04^{\mathrm{c}} \\
0.69 \pm 0.04^{\mathrm{d}}\end{array}$ & $\begin{array}{l}1.71 \pm 0.27 \\
1.78 \pm 0.28\end{array}$ \\
\hline $\begin{array}{l}\text { After ovariectomy } \\
\text { (Day 26) }\end{array}$ & $\begin{array}{l}\mathrm{H} \\
\mathrm{L}\end{array}$ & $\begin{array}{l}6 \\
6\end{array}$ & $\begin{array}{l}3.30 \pm 0.73 \\
3.79 \pm 0.84\end{array}$ & $\begin{array}{l}9.51 \pm 1.05 \\
8.36 \pm 0.92\end{array}$ \\
\hline
\end{tabular}

Within columns, there were significant differences (a versus $\mathrm{b}$, c versus $\mathrm{d}$, $P<0.05$; a versus $\mathrm{c}$, b versus $\mathrm{d}, P<0.01$ ).

During the follicular phase of the cycle, mean FSH concentrations were significantly greater in the L-line than H-line ewes (Table 1). By the luteal phase, there was no difference in mean FSH values between lines nor were there any significant differences after ovariectomy. In the $\mathrm{H}$-line ewes 

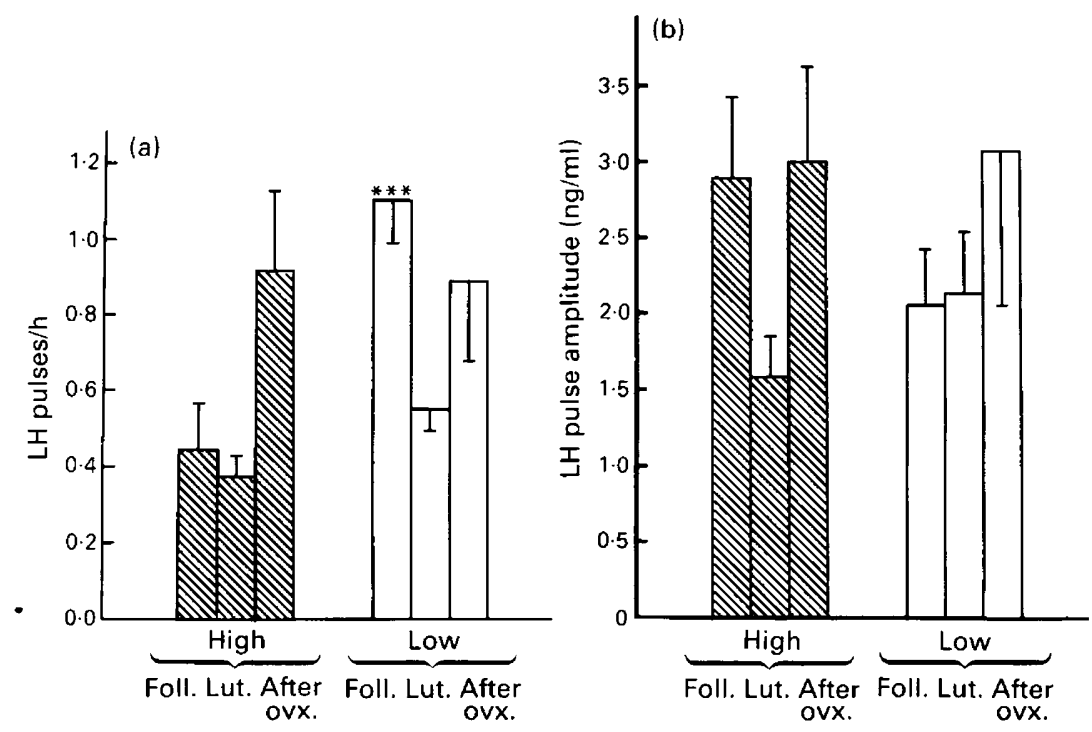

Fig. 1. Mean ( \pm s.e.m.) LH pulse frequency (a) and LH pulse amplitude (b) in ewes from the High and Low testis-selection lines during the follicular and luteal phases of the oestrous cycle and at 26 days after ovariectomy (Ovx.). ${ }^{* * *} P<0.01$ compared with low luteal and high follicular LH pulse frequencies.

FSH appeared to be lower during the follicular than the luteal phase but this difference was not significant. In the L-line ewes, mean FSH concentrations were similar in the follicular and luteal phases.

\section{Effect of ovariectomy and ovariectomy + oestradiol implant on gonadotrophin concentrations}

$L H$. The plasma concentrations of $\mathrm{LH}$ after ovariectomy and ovariectomy + oestradiol implant are shown in Fig. 2(a). During the first $2 \mathrm{~h}$ after ovariectomy, the plasma LH values in sheep of both lines without an implant fluctuated around basal levels of $\sim 1 \mathrm{ng} / \mathrm{ml}$. However, by $4 \mathrm{~h}$ after ovariectomy, the concentrations of LH had started to rise at the same rate in both lines, but this rate of increase was not maintained beyond $8 \mathrm{~h}$ after ovariectomy in the H-line ewes. A maximum $\mathrm{LH}$ concentration $(4.8 \pm 0.7 \mathrm{ng} / \mathrm{ml})$ was observed by $12 \mathrm{~h}$ after ovariectomy in the $\mathrm{L}$ line, whereas in the $\mathrm{H}$ line $\mathrm{LH}$ rose to around $3 \mathrm{ng} / \mathrm{ml}$ within $8 \mathrm{~h}$ and remained at this level for 4 days. By Day 6 after ovariectomy, there was no significant difference in mean plasma LH concentrations between the lines and, from Day 6-15 after ovariectomy, although the $\mathrm{H}$-line ovariectomized ewes showed higher $\mathrm{LH}$ values, this was not significant.

Oestradiol. Although the implants were soaked in tap water then ethanol, to remove excess steroids as described by Karsch et al. (1983), the mean concentration of oestradiol in peripheral plasma during the first $24 \mathrm{~h}$ after implant insertion $(12.8 \pm 1.6 \mathrm{pg} / \mathrm{ml})$ was greater than the equilibrium concentration of $5 \cdot 6 \pm 0.3 \mathrm{pg} / \mathrm{ml}$ observed on Day 4 after ovariectomy which was maintained to the end of the experiment. The latter was slightly higher than had been anticipated from previous studies.

The high concentrations of oestradiol observed during the first $24 \mathrm{~h}$ after ovariectomy depressed the concentration of LH to basal levels for $8 \mathrm{~h}$ in both groups of ovariectomized + implanted ewes. By $12 \mathrm{~h}$ after ovariectomy, the $\mathrm{LH}$ values had begun to rise in ewes of both lines with a greater rate of rise in the L-line ewes to give a maximum concentration of $3.2 \pm 0.3 \mathrm{ng} / \mathrm{ml}$ by $16 \mathrm{~h}$ after ovariectomy. A maximum value of $2.87 \pm 0.33 \mathrm{ng} / \mathrm{ml}$ was observed $20 \mathrm{~h}$ after ovariectomy in the $\mathrm{H}$-line ewes (ovariectomy + implant). From Day 2 to Day 15 after ovariectomy, the 

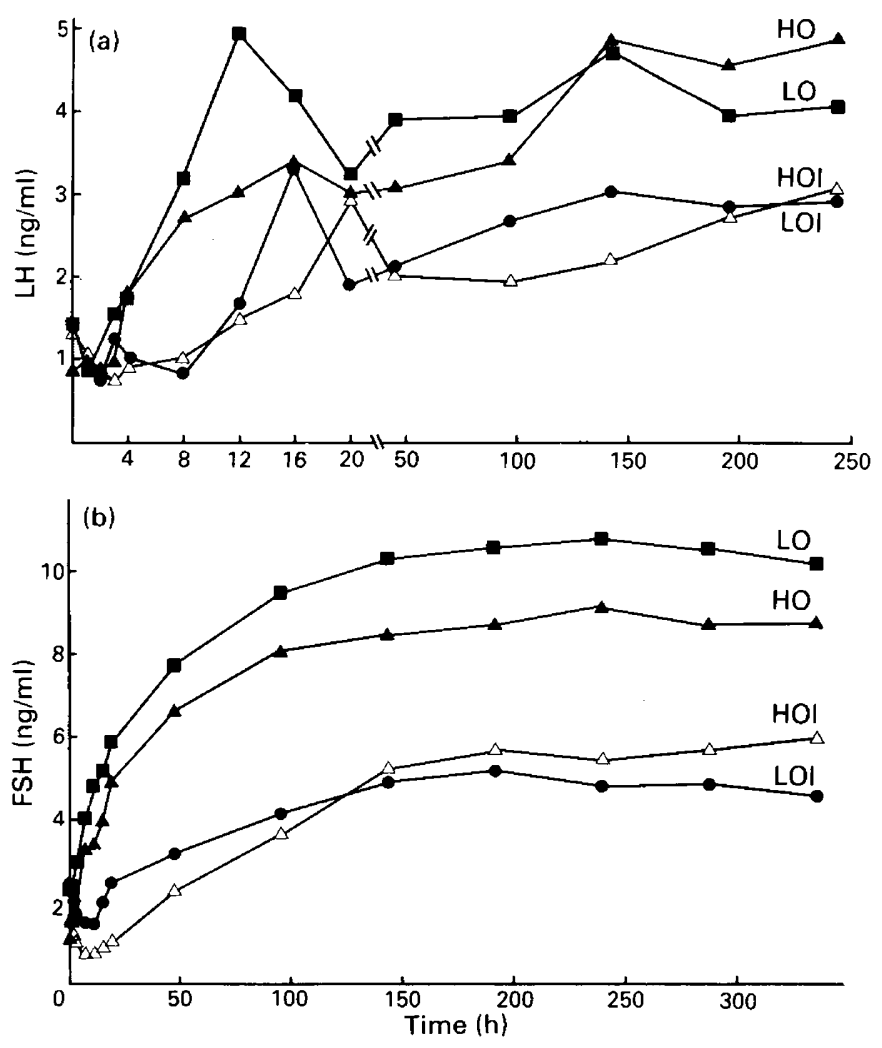

Fig. 2. Changes in (a) plasma LH and (b) plasma FSH after ovariectomy in ewes from the High and Low testis-selection lines. $\boldsymbol{\Delta}=$ High line ovariectomized; $\boldsymbol{\square}=$ Low line ovariectomized; $\Delta=$ High line ovariectomized + oestradiol implant; $\mathbf{O}=$ Low line ovariectomized + oestradiol implant. Values are means \pm s.e.m. expressed as the differences between the time of injection $(0 \mathrm{~min})$ and subsequent response.

mean concentrations of plasma LH were similar in each line and had risen to $\sim 3 \mathrm{ng} / \mathrm{ml}$ by Day 6 (Fig. 2a).

FSH. After ovariectomy alone, a rapid rise in plasma FSH concentrations over basal values was observed by $8 \mathrm{~h}$ and continued throughout the first $24 \mathrm{~h}$ after ovariectomy in the $\mathrm{H}$ - and L-line ewes (Fig. 2b). By $48 \mathrm{~h}$, the rate of increase in FSH in both lines was reduced, with the L-line ewes showing a significantly greater concentration by Day 6 which was maintained to Day 15 . However, during the period of rapid blood sampling 2 days after the last LHRH challenge (Day 26 after ovariectomy), no differences in mean FSH concentrations were detected.

In all ovariectomized ewes receiving an oestradiol implant, plasma FSH concentrations fell during the first $12 \mathrm{~h}$ after ovariectomy. The subsequent rise in FSH values was significantly faster in the L line although, from $48 \mathrm{~h}$ to 15 days after ovariectomy there was no significant difference between the lines for sheep carrying oestradiol implants. However, there were significant differences in plasma FSH concentrations between the ovariectomy alone and ovariectomy \pm oestradiol implant groups.

\section{Response to $L H R H$}

$L H$. The changes in LH and FSH concentrations, expressed as the difference in hormone levels between time of injection ( $0 \mathrm{~min})$ and the subsequent sampling times, are given in Fig. 3(a). There 
was a clear non-linear dose response in all groups with the $\mathrm{LH}$ response at the high dose $(5 \mu \mathrm{g})$ significantly higher than at the medium $(0.5 \mu \mathrm{g})$ and low $(0.05 \mu \mathrm{g})$ doses. There was no difference in LH response in any groups at the medium and low doses. At the high dose, the L-line ovariectomized ewes showed a significantly greater response than did all other groups. Overall, the L-line ovariectomized animals tended to have a greater response than did the $\mathrm{H}$-line ovariectomized ewes at all doses, while the L-line ovariectomized + implant ewes tended to have a lower response than did the corresponding $\mathrm{H}$ group.

FSH. As for LH, there was a clear non-linear dose-response in all groups (Fig. 3b). Although the differences for FSH were not so large as for $\mathrm{LH}$, the high dose elicited significantly greater responses in all 4 groups. In contrast to LH, the FSH response in the L-line groups at the medium and high doses was almost uniformly higher than at the low dose, although the differences were only of borderline significance. At all doses, there was no difference between the treatment groups.
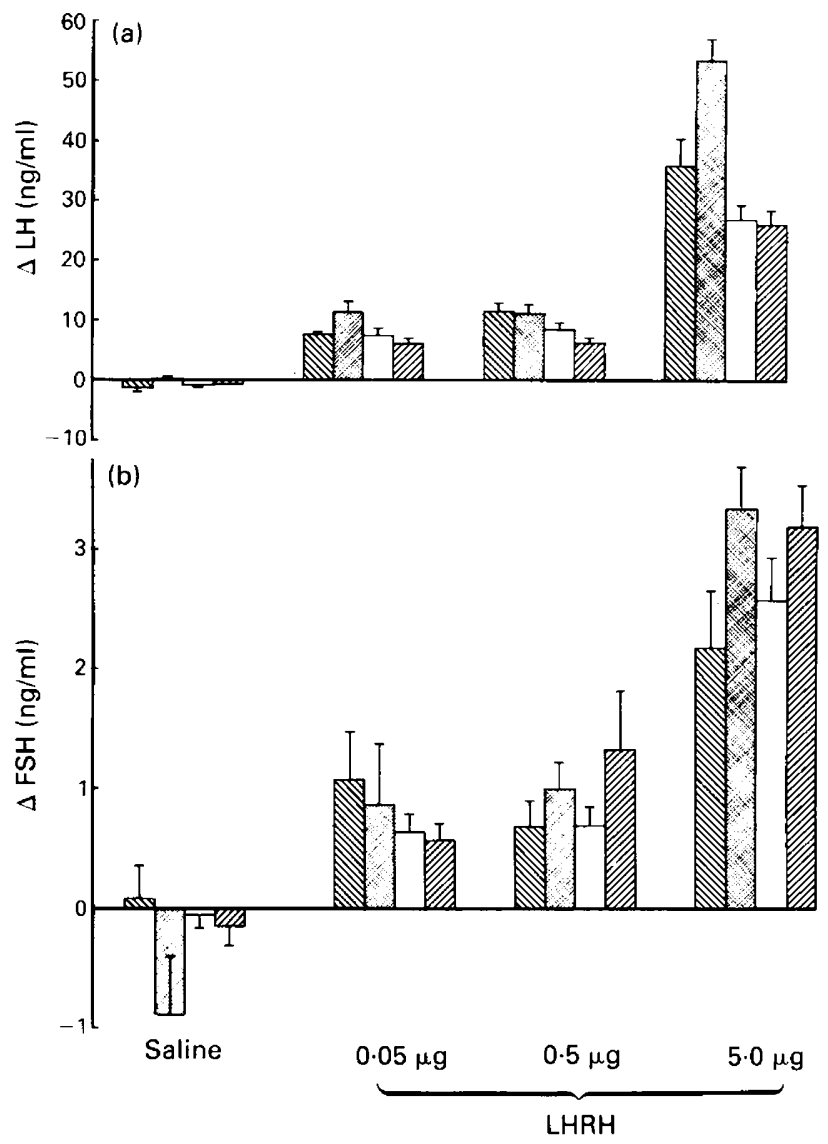

Fig. 3. Changes in (a) plasma $\mathrm{LH}$ and (b) plasma FSH after the injection of saline or $0 \cdot 05,0 \cdot 5$ or $5 \mu \mathrm{g} \mathrm{LHRH}$. $\mathbb{\mathbb { S }}=$ High line ovariectomized; = Low line ovariectomized; $\square=$ High line ovariectomized + oestradiol implant; $=$ Low line ovariectomized + oestradiol implant.

\section{Discussion}

Genetic selection for testis growth in the lamb led to marked changes in the dynamics of gonadotrophin secretion in the young male, but, as previously reported by Lee \& Land (1984), there was 
little change in ovulation rate in ewes from the selected lines. However, the present study shows that the selection did have a marked effect on the secretion of both LH and FSH. During the oestrous cycle, mean concentrations of LH were significantly lower in the $\mathrm{H}$ line in the luteal and follicular phase. In the L line, changes in mean LH were accounted for by an increase in pulse frequency between the luteal and follicular phases, but no such change in the LH pulse frequency occurred in the $\mathrm{H}$-line ewes, the increase in the follicular phase being due to an unexpected increase in pulse amplitude.

The frequency of LH pulses was originally thought to be progesterone dependent (Baird \& Scaramuzzi, 1976; Goodman \& Karsch, 1980). However, it is now generally accepted that an interaction between luteal progesterone and follicular oestrogen, acting at the hypothalamus to reduce the secretion of GnRH pulses, maintains the low LH pulse frequency during the luteal phase (Karsch et al., 1980; Martin, 1984). By inference, therefore, the reduction in frequency of LH pulses between the follicular and luteal phases of the oestrous cycle observed in the L-line ewes suggests that they are sensitive to changes in oestrogen and progesterone during the cycle. In contrast, the lack of variation in pulse frequency in the $\mathrm{H}$ line indicates that these animals are either less responsive to steroid feedback at the hypothalamus or steroid feedback from the ovary is similar in the follicular and luteal phases of the oestrous cycle. The latter would not be expected.

Oestrogen alone, acting at the pituitary, reduces LH pulse amplitude by decreasing pituitary responsiveness to GnRH (Goodman \& Karsch, 1980; Wright et al., 1981). There is no significant effect of progesterone on amplitude (Goodman et al., 1981) and other studies (Baird \& McNeilly 1981; Wallace et al., 1987) show similar pulse amplitudes throughout the cycle. During the follicular phase in the $\mathrm{H}$-line ewes, however, $\mathrm{LH}$ pulse amplitude increased. Whether this increase in amplitude could be due to lack of pituitary responsiveness to oestradiol or a deficiency in oestradiol secretion from the preovulatory follicles cannot be proved. However, no differences in ovulation rate were seen between the lines and, in addition, the number of matings/conception is higher in the L line ( 1.55 and 1.2 ; Lee \& Land, 1984), leading us to assume that there is no ovarian deficiency in the $\mathbf{H}$ line. Again, the results indicate the $\mathrm{H}$-line ewes to be insensitive to steroid feedback at the level of the pituitary gland as well as the hypothalamus. Unfortunately, this lack of sensitivity to steroid feedback in the $\mathrm{H}$ line is not consistent as, after ovariectomy and oestradiol implantation, LH concentrations are suppressed for longer in sheep of this line in the first $24 \mathrm{~h}$ after implantation. If there is a possible deficiency in oestradiol production during the luteal phase in this line, the sudden increase in circulating oestradiol after ovariectomy and implantation may be crucial to the LH response.

During the follicular phase, ewes from both lines exhibited a decline in FSH concentrations. This parallels previous observations and is probably due to increased oestradiol (Baird \& McNeilly, 1981; McNeilly, 1984) and inhibin concentrations, as values of both hormones have been shown to increase within the preovulatory follicles at this time (Tsonis et al., 1983) and be important in the control of FSH release (Martin et al., 1986). However, in the $\mathrm{H}$-line ewes, this decrease in FSH in the follicular phase was significantly greater than that observed in the L-line ewes.

For the maintenance of $\mathrm{LH}$ pulse frequency, and the increase in pulse amplitude in the $\mathrm{H}$ line during the follicular phase to have arisen from a reduction in oestradiol concentration, FSH release in the $\mathrm{H}$ line would have to be exceptionally sensitive to oestrogen feedback. The unusual FSH and LH patterns are, therefore, most likely to have arisen from differences in sensitivity to steroid feedback. The evidence from the study of the oestrous cycle therefore indicates differential sensitivity to steroid feedback in the two lines. The response to ovariectomy and oestrogen implants is essentially similar in both lines. The differential sensitivity must, therefore, arise from interactions with progesterone. This suggests that the selection has altered the sensitivity of the hypothalamicpituitary axis to the negative feedback effects of $\Delta^{4}$ steroids since a previous study of ram lambs from the same selection lines showed that the $\mathrm{H}$-line lambs were more sensitive to the negative feedback effect of testosterone (McNeilly et al., 1986).

While there was a significant response to LHRH at all dose levels, there were surprisingly no differences in the LH or FSH response at the medium relative to the low dose levels in all groups. 
This might be due to the time since ovariectomy and implant insertion because the response is known to be reduced in long-term ovariectomized animals (Montgomery et al., 1985). In addition, the similarity at all dose levels of the response in the H-line ewes, whether there was oestradiol present or not, gives further evidence that the $\mathrm{H}$-line animals were relatively insensitive to oestradiol feedback when compared to the L-line ewes.

The present study was designed to determine whether there were endocrine responses in adult females from lines selected on juvenile testis size. Comparing our studies in ram lambs and adult ewes is very difficult. Collectively, however, they show that selection for testis size has altered the quantitative control of gonadotrophin release in both the ram lamb and adult ewes and demonstrate that the expression of genes controlling gonadotrophin release is not limited by age or sex. Further studies of ram lambs involving use of steroid implants in castrates to quantify the response lines are in progress.

We thank the staff of the Dryden Laboratory, Roslin, for surgical assistance and care of animals; Mr D. McBride for assistance with oestradiol assays; NIAMDD, U.S.A., for radioimmunoassay reagents; and Mrs J. Cherrie for typing the manuscript.

\section{References}

Baird, D.T. \& McNeilly, A.S. (1981) Gonadotrophic control of follicular development and function during the oestrous cycle of the ewe. J. Reprod. Fert., Suppl. 30, 119-133.

Baird, D.T. \& Scaramuzzi, R.J. (1976) Changes in the secretion of ovarian steroids and pituitary luteinizing hormone in the peri-ovulatory period in the ewe: the effect of progesterone. J. Endocr. 70, 237-245.

Goodman, R.L. \& Karsch, F.J. (1980) Pulsatile secretion of luteinizing hormone: differential suppression by ovarian steroids. Endocrinology 107, 1286-1290.

Goodman, R.L., Bittman, E.L., Foster, D.L. \& Karsch, F.J. (1981) The endocrine basis of the synergistic expression of luteinizing hormone by estradiol and progesterone. Endocrinology 109, 1414-1417.

Hanrahan, J.P. \& Quirke, J.F. (1982) Selection on ovulation rate in sheep aided by the use of superovulation and egg transfer. In Proc. Wld. Congr. Sheep and Beef Cattle Breeding, pp. 329-335. Eds R. A. Barton \& W. C. Smith. Dunmore Press Ltd, Palmerston North.

Islam, A.B.M.M., Hill, W.G. \& Land, R.B. (1976) Ovulation rate of lines of mice selected for testes weight. Genet. Res. 27, 23-32.

Karsch, F.J., Legan, S.J., Ryan, K.D. \& Foster, D.L. (1980) Importance of oestradiol and progesterone in regulating the $\mathrm{LH}$ secretion and estrous behaviour in the sheep estrous cycle. Biol. Reprod. 24, 404-413.

Karsch, F.J., Foster, D.L., Bittman, E.L. \& Goodman, R.L. (1983) A role for estradiol in enhancing luteinizing hormone pulse frequency during the follicular phase of the estrous cycle of sheep. Endocrinology 113, 1333-1339.

Knight, T.W. (1984) Testicular growth and size in rams from flocks of different reproductive potential. N.Z. J. agric. Res. 27, 179-187.

Land, R.B. (1973) The expression of female sex-limited characters in the male. Nature, Lond. 241, 208-209.

Lee, G.J. \& Land, R.B. (1984) Testis size and LH response to LH-RH as male criteria of female repro- ductive performance. In Genetics of Reproduction in Sheep, pp. 333-341. Eds R. B. Land \& D. W. Robinson. Butterworths, London.

Martin, G.B. (1984) Factors affecting the secretion of luteinizing hormone in the ewe. Biol. Rev. 59, 1-87.

Martin, G.B., Wallace, J.M., Taylor, P.L., Fraser, H.M., Tsonis, C.G. \& MeNeilly, A.S. (1986) The roles of inhibin and gonadotrophin releasing hormone in the control of gonadotrophin secretion in the ewe. $J$. Endocr. 111, 287-296.

Martensz, N.A., Baird, D.T., Scaramuzzi, R.T. \& Van Look, P.F.A. (1976) Androstenedione and the control of luteinizing hormone in the ewe during anoestrus. J. Endocr. 69, 227-237.

McNeilly, A.S. (1984) Changes in FSH and the pulsatile secretion of LH during the delay in oestrus induced by treatment of ewes with bovine follicular fluid. $J$. Reprod. Fert. 72, 165-172.

McNeilly, J.R., Fordyce, M., Land, R.B., Lee, G.J. \& Webb, R. (1986) Endocrine differences in rams after genetic selection for testis size. J. Reprod. Fert. 76, 131-140.

Montgomery, G.W., Martin, G.B. \& Pelletier, J. (1985) Changes in pulsatile LH secretion after ovariectomy in Ile-de-France ewes in two seasons. J. Reprod. Fert. 73, 173-183.

Purvis, I.W., Piper, L.R., Edey, T.N. \& Kilgour, R.J. (1988) The genetic relationship between ovulation rate and testicular diameter in a random-breeding Merino flock. Livestock Prodn Sci. 18, 35-54.

Tsonis, C.G., Quigg, H., Lee, V.W.K., Leversha, L, Trounson, A.O. \& Findlay, J.K. (1983) Inhibin in individual ovine follicles in relation to diameter and atresia. J. Reprod. Fert. 67, 83-90.

Walkley, J.R.W. \& Smith, C. (1980) The use of physiological traits in genetic selection for litter size in sheep. J. Reprod. Fert. 59, 83-88.

Wallace, J.M., Martin, G.B. \& McNeilly, A.S. (1987) Changes in the secretion of LH pulses, FSH and 
prolactin during the preovulatory phase of the oestrous cycle of the ewe and the influence of treatment with bovine follicular fluid during the luteal phase. $J$. Endocr. 116, 123-135.

Webb, R., Baxter, G., McBride, D., Nordblom, G.D. \& Shaw, M.P.K. (1985a) The measurement of testosterone and oestradiol-17 $\beta$ using iodinated tracers and incorporating an affinity chromatography extraction procedure. J. Steroid Biochem. 23, 1043-1051.
Webb, R., Baxter, G., Preece, R.D., Land, R.B. \& Springbett, A.J. (1985b) Control of gonadotrophin release in Scottish Blackface and Finnish Landrace ewes during seasonal anoestrus. $J$. Reprod. Fert. 73, 369-378.

Wright, P.J., Geytenbeek, P.E., Clarke, I.J. \& Findlay, J.K. (1981) Evidence for a change in oestradiol negative feedback and LH pulse frequency in post-partum ewes. J. Reprod. Fert. 61, 97-102.

Received 18 January 1988 